\title{
Dédicace à Richard Marienstras
}

\section{Dominique Goy-Blanquet}

\section{(2) OpenEdition \\ Journals}

Édition électronique

URL : https://journals.openedition.org/shakespeare/1651

DOI : 10.4000/shakespeare.1651

ISSN : 2271-6424

Éditeur

Société Française Shakespeare

Édition imprimée

Date de publication : 1 mars 2011

Pagination : i

ISBN : 2-9521475-7-4

\section{Référence électronique}

Dominique Goy-Blanquet, « Dédicace à Richard Marienstras », Actes des congrès de la Société française Shakespeare [En ligne], 28 | 2011, mis en ligne le 15 février 2011, consulté le 21 septembre 2021. URL http://journals.openedition.org/shakespeare/1651 ; DOI : https://doi.org/10.4000/shakespeare.1651 


\section{Shakespeare et la Cité}

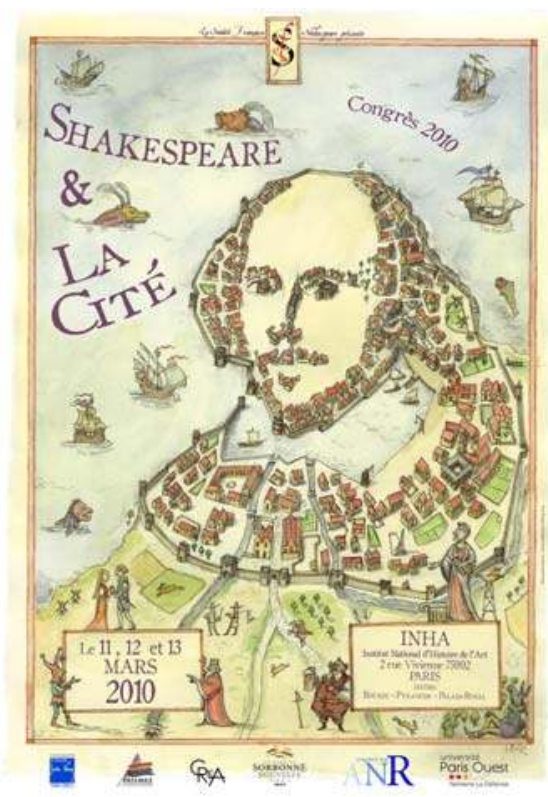

actes du Congrès

organisé par la

SOCIÉTÉ FRANÇAISE SHAKESPEARE

les 11,12 et 13 mars 10

textes réunis par

Pierre KAPITANIAK

sous la direction de

Dominique GoY-BLANQUET 
COUVERTURE :

Edouard Lekston 2010

conception graphique et logo

Pierre Kapitaniak

\section{(C) 2010 Société Française Shakespeare \\ Institut du Monde Anglophone}

Université de Paris III - Sorbonne Nouvelle

5 rue de l'École de Médecine 75006 Paris

www.societefrancaiseshakespeare.org

Tous droits de traduction, de reproduction et d'adaptation réservés pour tous les pays 
ichard Marienstras nous a quittés le 22 février dernier, trop tôt pour voir l'hommage qui lui est rendu dans ce recueil d'Actes. Ils lui étaient dès l'origine dédiés, car la Cité est au cœur de la pensée qu'il nous a transmise au fil de ses livres et ses enseignements, dans les murs ou hors la loi, seuls ou ensemble, de Coriolan à Timon, Falstaff ou Prospero, d'Etre un peuple en diaspora au Proche et le lointain et Shakespeare au XXI siècle. Pour ma part j'ai reçu de lui le meilleur de ce que m'a donné l'université, je pense le meilleur de ce que l'université peut offrir. Le premier cours auquel j'ai assisté n'était pas strictement universitaire, c'était une brillante relecture du Songe et de Richard III qu'il mettait en scène avec un groupe d'étudiants, et qui fut pour moi déterminante. Devenus enseignants, plusieurs d'entre nous continuaient à se glisser dans ses salles de cours, parce que sa parole éclairait les textes les plus arides, les plus enfouis dans le passé. Je le revois insistant du sourire et du geste sur une fine nuance qui nous avait totalement échappés, puis l'ouvrant à la dimension philosophique de l'œuvre. Je repense aux longues conversations avec lui et son épouse Élise l'historienne, leur courage à tous deux contre la maladie, les retournements politiques, les déceptions qui n'ont jamais entamé leur lucidité ni leur droiture. Je repense enfin à sa définition de la tragédie, la chute ontologique qu'entraine la disparition du héros, le sentiment d'une perte irremplaçable pour la communauté : «We that are young / Shall never see so much, nor live so long. »

Au revoir Richard, merci. 